\title{
Complete dehiscence and unseated prosthetic aortic valve causing severe aortic insufficiency: an unusual complication of prosthetic valve endocarditis
}

\author{
Rama K Krishna, Paola Casanova, Maiteder Larrauri-Reyes, Orlando Santana
}

Division of Cardiology, Columbia University, Mount Sinai Medical Center, Miami Beach, Florida, USA

\section{Correspondence to} Dr Orlando Santana, orlando.santana@msmc.com

Accepted 8 October 2014

CrossMark

\begin{tabular}{l}
\hline To cite: Krishna RK, \\
Casanova P, Larrauri- \\
Reyes M, et al. BMJ Case \\
Rep Published online: \\
[please include Day Month \\
Year] doi:10.1136/bcr-2014- \\
206925 \\
\hline
\end{tabular}

\section{DESCRIPTION}

Images of a female patient's status post bioprosthetic aortic valve replacement with aortic root sparing and mitral valve repair. She presented with shortness of breath and low-grade fever 3 months after surgery. Transthoracic echocardiography (TTE) showed a freely mobile and rocking prosthetic aortic valve, totally dislodged and seeming to be stuck at the sinotubular level (figure 1), with a severe paravalvular leak causing aortic insufficiency (video 1). Holodiastolic flow reversal was observed in the descending thoracic aorta and normal left ventricular function. Transesophageal echocardiography (TEE) confirmed the findings (figure 2). The patient had positive blood cultures for coagulase-negative Staphylococcus and after an initial period of aggressive antibiotic therapy, she underwent minimally invasive aortic valve replacement re-do surgery (Bentall procedure) and made a gradual recovery (figure 3 ).

The dehiscence of a prosthetic aortic valve is an uncommon complication that is reported in $0.1 \%$ to

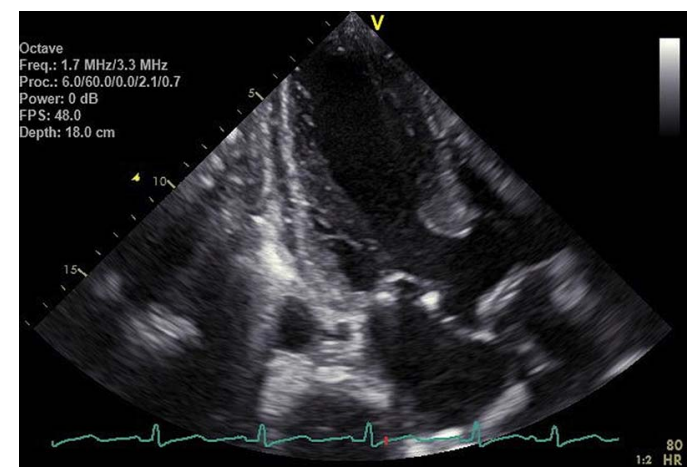

Figure 1 Transthoracic echocardiography apical view: dehisced and unseated bioprosthetic aortic valve.

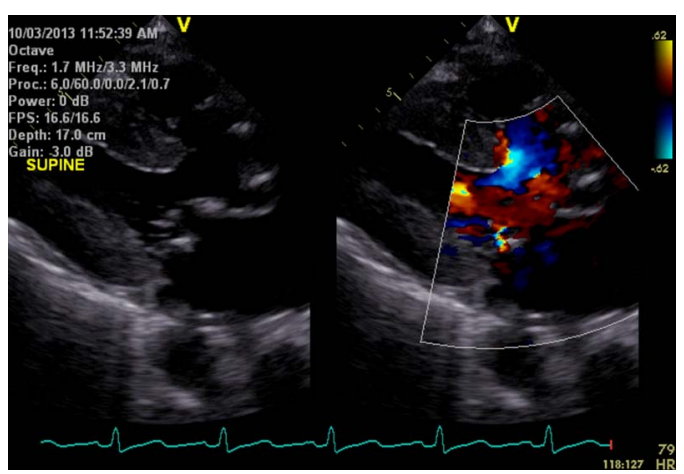

Video 1 TTE parasternal long axis (LAX): Dehisced and unseated bio-prosthetic aortic valve with severe paravalvular leak and aortic insufficiency.

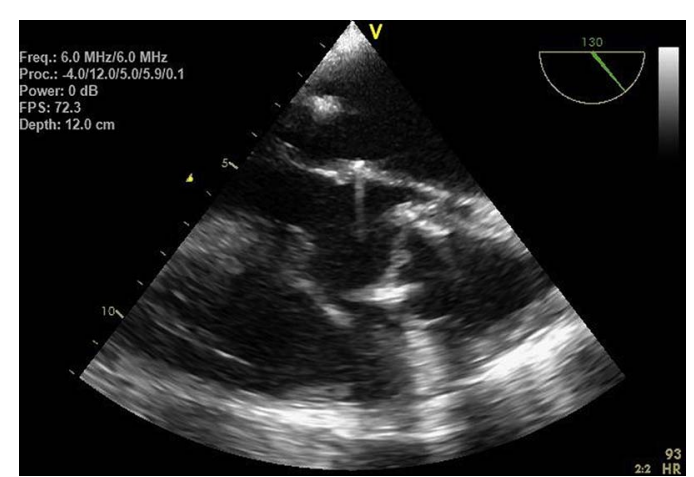

Figure 2 Transesophageal echocardiography long axis: dehisced and unseated bioprosthetic aortic valve.

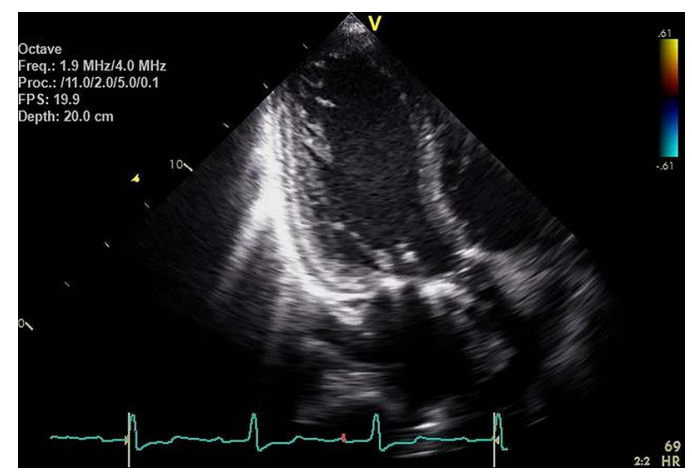

Figure 3 Transthoracic echocardiography apical view: postoperative image of the newly placed bioprosthetic aortic valve.

$1.3 \%$ of patients who undergo aortic valve replacement. ${ }^{1}$ The known risk factors for the dehiscence are bacterial endocarditis, concomitant aneurysm of the ascending aorta and severe calcification of the native aortic valve. Dehiscence of the aortic valve has also been noted with non-infectious aortitis and associated vasculitis. ${ }^{2}$ Total dislodgement with

\section{Learning points}

- Prosthetic valve endocarditis should be suspected with new murmur and fever in patients with a history of valve replacement.

- Transesophageal echocardiography is helpful to confirm the diagnosis.

- Complete dehiscence of a prosthetic valve is unusual but is commonly associated with infective endocarditis. 


\section{Images in...}

unseating of the bioprosthesis is very uncommon, hence we presented these striking images of this complication.

Competing interests None.

Patient consent Obtained.

Provenance and peer review Not commissioned; externally peer reviewed.

\section{REFERENCES}

1 Tominaga R, Kurisu K, Ochiai Y, et al. A 10-year experience with the Carbomedics cardiac prosthesis. Ann Thorac Surg 2005;79:784-9.

$2 \mathrm{~K} 00 \mathrm{HJ}$, Yang DH, Kang JW, et al. Demonstration of prosthetic aortic valve dehiscence in a patient with noninfectious aortitis by multimodality imaging findings of echocardiography and computed tomography. Circulation 2013;128:759-61.

Copyright 2014 BMJ Publishing Group. All rights reserved. For permission to reuse any of this content visit http://group.bmj.com/group/rights-licensing/permissions.

BMJ Case Report Fellows may re-use this article for personal use and teaching without any further permission.

Become a Fellow of BMJ Case Reports today and you can:

- Submit as many cases as you like

- Enjoy fast sympathetic peer review and rapid publication of accepted articles

- Access all the published articles

- Re-use any of the published material for personal use and teaching without further permission

For information on Institutional Fellowships contact consortiasales@bmjgroup.com

Visit casereports.bmj.com for more articles like this and to become a Fellow 